\title{
Event Based Modeling of a Watershed Using HEC-HMS
}

\author{
H.K. Nandalal and U.R. Ratnayake
}

\begin{abstract}
Modeling a watershed can be very much useful to quantify water resources for effective system management. Rainfall runoff models are very much useful in forecasting floods, which will enable taking mitigation measures. Kalu-Ganga River basin in Sri Lanka is subjected to frequent floods. This paper presents a rainfall-runoff model developed for this basin using HEC-HMS lumped conceptual hydrologic model. Two different models, one having four sub basins and the other having ten sub basins were formulated. They were calibrated and verified using four historical flood events. Streamflow data at three gauging stations along the river were used in the calibration and verification. The resulting hydrographs at these three gauging stations were compared with the observed hydrographs based on flood peaks, time to peak and the Nash Sutcliffe coefficient. The results show the suitability of the HECHMS software in the modeling of the Kalu-Ganga River basin. Further the results of the two models indicate that there is no impact of the number of sub basins considered in the modeling of the basin on the prediction of floods due to rainfalls.
\end{abstract}

Key Words: Watershed Modeling, Scale effect

\section{Introduction}

Hydrology as defined by Penman, 1961 is the science that answers the question, "What happens to the rain?" Modeling a watershed to answer this question is a very complex task involving collection of necessary data, selection of methods to analyze, availability of affordable software and the knowledge of the watershed concerned. Modeling a natural event like run-off from a rainfall will help water resources managers to mitigate the consequences of floods in advance. Modern day technology and toois help engineers to model natural environment. Tools like Geographical Information Systems (GIS) and watershed models contribute a lot for the modeling of natural events like floods. Advances in technology of computers, availability of data and necessary software also make modeling an easy task. Singh and Woolhiser (2002) provided a historical perspective of watershed modeling, a short outline of currently used models, and reflects on new developments. However, modeling a watershed not only needs necessary software, data and models but also it needs a sound knowledge of the particular watershed. It is important to analyze watershed and the data available in detail before applying a model.

Watershed hydrologic modeling and the associated model calibration and verification require a large amount of spatial and temporal data (e.g., topography, land use, land covers, type of soil, rainfall and flow monitoring data). In practice the availability and quality of these data are often an issue one needs to cope with. Sometimes, one has to compromise the overall modeling quality because of insufficient highresolution data for developing, calibrating, and validating a model (Chu, 2009). Therefore, it is a crucial task to model a river basin under limited data availability.

Hydrological models are being developed and applied in increasing number and variety. All hydrological models are simplified representations of the real world. Models can be either physical (e.g. laboratory scale models), electrical analogue or mathematical. The physical and analogue models have been very important in the past. However, the mathematical group of models is by far the most easily and universally applicable, the most widespreaded and the one with the most rapid development with regard to scientific bases and application (Refsgaard, 1996).

Eng. (Mrs.) H.K.Nandalal, BSc Eng, MSc, MIE(Sri Lanka), CEng, Lecturer, Department of Civil Engineering, University of Peradeniya,

Eng.(Dr.) U. R. Ratmayake, BSC, MSc, PhD, MIE(Sri Lanka), CEng, Senior Lecturer, Department of Civil Engineering, Unizersity of Peradeniya, 
The two classical types of hydrological models are the deterministic and the stochastic. The deterninistic models use data available as it is while the stochastic models use the statistical nature of available data to predict rainfall runoff. The deterministic models can be classified according to whether the model gives a lumped or distributed description of the considered area, and whether the description of the hydrological processes is empirical, conceptual, or more physically-based. Therefore, modern day hydrological models can be classified into empirical models, lumped conceptual models and distributed physically-based models. Out of these models empirical models need accurate rainfall and runoff data for calibration while distributed physically based models need a large number of spatial characteristics of the area and meteorological data to calculate the runoff for a given rainfall.

Lumped conceptual models need moderately accurate rainfall and runoff data and average physical characteristics of the area concerned. Parameters of these models can be calibrated and verified with historical data available. Most of the hydrological models available today come under this category. The Hydrologic Engineering Center's Hydrologic Modeling System, HECHMS (USACE-HEC 2006) also falls into this category.

Modeling also can be event based or continuous. Event based calculations need initial conditions while continuous models need data of soil type to calculate soil moisture content and atmospheric data as well to calculate evaporation losses.

The goal of the current study is to verify the applicability of the Hydrologic Engineering Center's Hydrologic Modeling System, HECHMS, on event based modeling under two scenarios of sub basin scale for Kalu-Ganga River basin located in the South West slopes of Sri Lanka. Data for four rainfall events were used to calibrate and validate the model.

\section{Study Area}

The Kalu-Ganga River watershed covers 2658 $\mathrm{km} 2$ and is dominant by forest, residential and agricultural cropland land use types. Kalu-Ganga River is still an untamed river compared to the other rivers in the country though it captures a large amount of rainfall and drains freely to the Ocean at Kalutara (Figure 1). The catchment experiences an average annual rainfall of 4000 $\mathrm{mm}$. It varies from $2800 \mathrm{~mm}$ in lower reaches to $5300 \mathrm{~mm}$ in higher elevations. Geographically it lies between the $6.32^{\circ} \mathrm{N}$ and $6.90^{\circ} \mathrm{N}$, and $79.90^{\circ} \mathrm{E}$ and $80.75^{\circ} \mathrm{E}$ as per WGS84 coordinate system and flows from a height of about $2,250 \mathrm{~m}$ MSL.

Tributaries of the Kalu-Ganga River collect water from Sri-Pada and Sinharaja virgin rainforests and quickly drain from its upper catchments. Rainfalls on the Sri-Pada rainforest flow through a length of about $36 \mathrm{~km}$ and from an elevation of about 2,250 m MSL to $14 \mathrm{~m}$ MSL at Ratnapura town. There onwards the Kalu-Ganga River travels through a comparatively flat terrain of $14 \mathrm{~m}$ MSL to sea level through a distance of about $70 \mathrm{~km}$ collecting a large amount of water flowing from the other tributaries on the way making the lower reaches of the river prone to frequent floods.

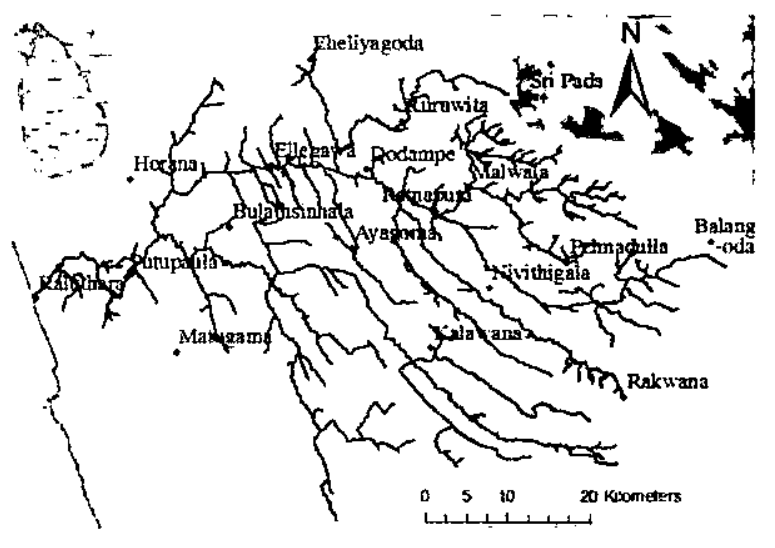

Figure 1. Kalu-Ganga River network on DEM

\section{Data}

\section{Terrain data}

Digital Elevation Model (DEM) data of the river basin is a requirement to apply HEC-GeoHMS (USACE-HEC-GeoHMS, 2006) model to develop the basin model. DEM data can be obtained from on-line sources and also can be developed using digital contour maps. However, developing a DEM using contour maps is an expensive procedure since it needs fine contour maps in the scale of at least 1:10,000. Availability and applicability of freely available on-line data for the Kalu-Ganga River basin has been discussed in Nandalal and Ratnayake (2008). For this study the Shuttle Radar Topography Mission (SRTM) DEM (Jarvis et al., 2008) data with $90 \mathrm{~m}$ grid resolution, which is freely available on-line is used. 


\section{Rainfall data}

Daily rainfall records from 01st January 1991 to 31st December 1994 of thirteen rainfall gauging stations lying in and around Kalu-Ganga River basin were taken from the Department of Meteorology, Sri Lanka and used in this model. Aggregated rainfall for the basin is calculated using the Thiessen polygon method as shown in Figure 2. Four high rainfall events shown in Table 1 were selected out of the rainfall data series to calibrate and validate the model for the basin.

The event in November 1992 was used to calibrate the model while the others were used to validate the model.

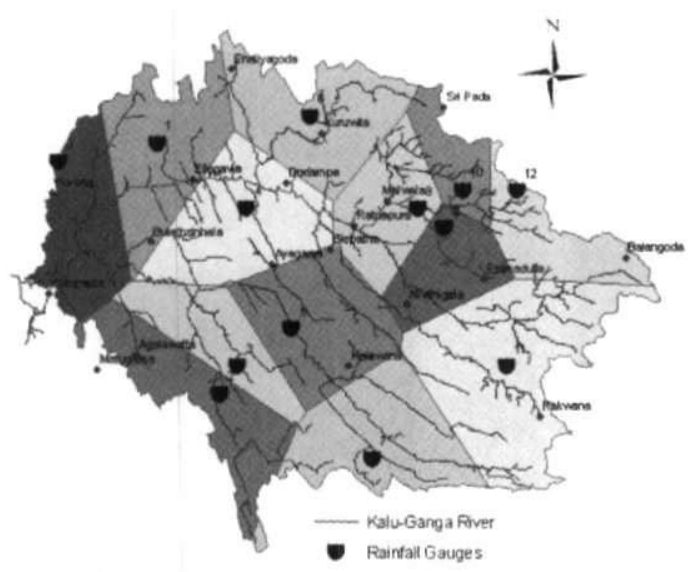

Figure 2. Rainfall gauging stations and the developed Thiessen polygons

Table 1. Rainfall events selected

\begin{tabular}{|l|l|}
\hline Event & Time period \\
\hline 1992 November & 13 days \\
\hline 1993 May & 26 days \\
\hline 1993 October & 17 days \\
\hline 1994 May & 34 days \\
\hline
\end{tabular}

\section{Discharge data}

Discharge data are very much important in the calibration and validation process of the model. Daily discharge data at three main gauging stations Ratnapura, Ellagawa and Putupaula along Kalu-Ganga River were obtained from the Department of Irrigation of Sri Lanka for the same period as for rainfall data to use in this study.

\section{Model Development}

In the process of model development, at first the basin model has to be developed either by HEC-GeoHMS with DEM or by feeding data into HEC-HMS itself. In this study the basin

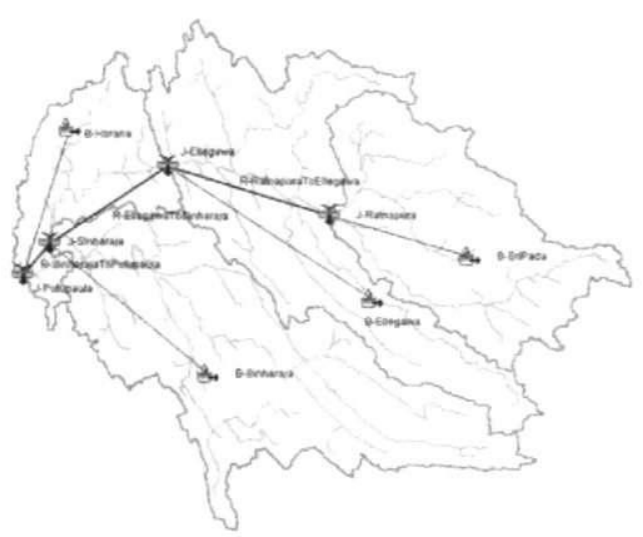

Figure 3. River Basin model with 4 sub catchments

model was developed by HEC-GeoHMS using the DEM model of the study area clipped from the SRTM DEM (Jarvis et al., 2008) data with 90 $\mathrm{m}$ grid resolution.

\subsection{HEC-GeoHMS 1.1}

HEC-GeoHMS is a geospatial hydrology toolkit for engineers with limited GIS experience. It is an extension package used in ArcView software and had been used extensively in modeling watersheds; two of recent applications are Bakir and Xingnan (2008) and Khakbaz et.al (2009). In this study, HEC-GeoHMS is used to derive river network of the basin and to delineate sub basins and the basin from the DEM of the Kalu-Ganga River basin.

When the number of sub basins increases, the spatial variation of the characteristics of the basin can be included efficiently in the model. To study that effect two types of basin models were developed, one with 4 sub basins and the other with 10 sub basins as shown in Figures 3 and 4 , respectively.

These basin models were imported to the HECHMS where there are several options available to derive rainfall runoff accounting for loss, transformation, and base flow calculation from a watershed. Simplest models with least number of parameters were selected because the detailed data such as soil type, land cover, land use and rainfall runoff data taken at smaller time intervals are not available. Calibrating many parameters for increased accuracy cannot be justified under this condition and same accuracy in calibrating is achieved with least number of parameters.

\subsection{HEC-HMS}

HEC-HMS (version 3.01) is hydrologic modeling software that includes many well-known and well-applicable hydrologic methods to simulate 
rainfall-runoff process in river basins (USACEHEC 2006). It consists of several models for

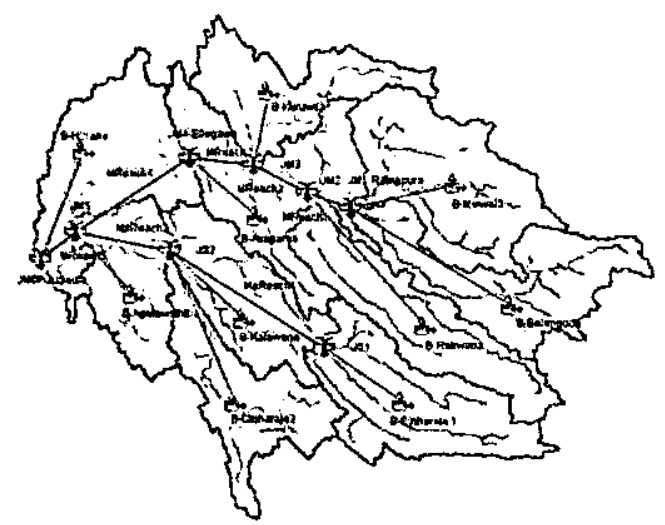

Figure 4. River Basin model with 10 sub catchments

calculation of losses and runoff due to a single rainfall event or a continuous rainfall. Application of HEC-HMS for modeling watersheds is extensive and some of the recent applications are Knebla et.al. (2003), Al-Sabhan et.al. (2003), Neary et.al. (2004), Pingel et.al. (2005) and Chu and Steinman (2009).

\subsubsection{Modeling Losses}

During a given rainfall, water is continually being abstracted to moisten the upper levels of the soil surface; however, this infiltration is only one of many continuous abstractions. Rainfall is also intercepted by trees, plants, and roof surfaces, and at the same time is evaporated (Viessnan and Lewis, 2003). Therefore, losses can be mainly described as initial and continuous. HEC-HMS program considers that all land and water in a watershed can be categorized as either directlyconnected impervious surface or pervious surface. Directly-connected impervious surface in a watershed is that portion of the watershed for which all contributing precipitation runs off, with no infiltration, evaporation, or other volume losses. Precipitation on the pervious surfaces is subjected to losses. The models available for the calculation of cumulative losses are:

- the initial and constant-rate model

- the deficit and constant-rate model

- the SCS curve number loss model and

- the Green and Ampt loss model

Out of these models the initial and constant model was selected for this study which needs only two parameters. The initial and constant-rate model includes one parameter (the constant rate) and one initial condition (the initial loss). These represent physical properties of the watershed soils, land use and the antecedent condition (USAE-HEC 2006).
The underlying concept of the initial and constant-rate loss model is that the maximum potential rate of precipitation loss is constant throughout an event after the initial loss. These two parameters can be calibrated with the available gauged runoff data.

\subsubsection{Modeling Direct Runoff}

This process refers to the transformation of precipitation excess into point runoff. HECHMS allows calibrating a few different models including, at the event based level:

\section{- Clark's model - Snyder's model \\ - SCS-UH model - Kinematic wave model}

Clark's model is a synthetic unit hydrograph that utilizes an instantaneous unit hydrograph (Clark, 1945). This widely used method is often called the time-area method and has appeared in several computer programs for hydrograph analysis. Clark's model is used in this study since it needs a small number of parameters.

Application of the Clark model requires calibration of only two parameters:

- Time of concentration of watershed tc.

- Storage coefficient, $R$.

Both of these parameters can be estimated via calibration if gauged precipitation and stream flow data are available. Though $\mathrm{R}$ has units of time, there is only a qualitative meaning for it in the physical sense. Clark (1945) indicated that $\mathrm{R}$ can be computed as the flow at the inflection point on the falling limb of the hydrograph divided by the time derivative of flow.

\subsubsection{Modeling Baseflow}

Baseflow is the sustained or "fair-weather" runoff of prior precipitation that was stored temporarily in the watershed, plus the delayed subsurface runoff from the current storm. The program includes three alternative models of baseflow:

- Constant, monthly-varying value

- Exponential recession model

- Linear-reservoir volume accounting model

Exponential recession model was selected for this study because it was found to be the one fitted well for the Kalu-Ganga River basin. The parameters of this model include the initial flow, the recession ratio, and the threshold flow. The initial flow is the likely average flow that would 
occur at the start of the storm runoff. For frequent events, the initial flow might be the average annual flow in the channel (USAE-HEC, 2006). The recession constant, $k$, depends upon the source of baseflow. The recession constant can be estimated if gauged flow data are available.

\subsubsection{Modeling Channel flow}

Channel flow model or routing model is used to model flow from upper catchment to the outlet of downstream catchment. The routing models available in HEC-HMS include:

\section{- Lag - Muskingum - Modified Puls, - Kinematic-wave - Muskingum Cunge}

Reaches of the Kalu-Ganga River behave differently; therefore both lag model and Muskingum model are used; lag model is used for steeper reaches and Muskingum model is used for reaches of gradual slope near coast. The lag model is the simplest routing model and it has only one parameter. Outflow hydrograph in it is simply the inflow hydrograph, but with all ordinates translated (lagged in time) by a specified duration. The flows are not attenuated, so the shape is not changed. This model is widely used, specially in urban drainage channels (Pilgrim and Cordery, 1993). Muskingum model needs calibration of two parameters; $\mathrm{K}$, travel time of the flood wave through routing reach; and $X$, dimensionless weight which corresponds to the attenuation of the flood wave as it moves through the reach. However, it was subjected to discussion upon applicability of this model for flood wave propagation where there are large flat flood plains (Dooge et al., 1982, Tung, 1985 and Yoon and Padmanabhan, 1993).

\subsubsection{Model Calibrations}

Parameters for each model should be entered as input to the model to obtain the simulated runoff hydrographs. Some of the parameter may be estimated by observation and measurements of stream and basin characteristics, but some of them can only beestimated through trial and error calibration for best fit. The model parameters are usually calibrated, i.e. in the presence of rainfall and runoff data the optimum parameters are found as a result of a systematic search process that yields the best fit between the observed runoff and the computed runoff. In HEC-HMS two different search algorithms (Nelder and Mead search algorithm and Univariate Gradient search algorithm) are provided that moves from the initial estimates to the final best estimates.
Univariate Gradient search algorithm was selected for this study. A variety of objective functions are provided to measure the goodness of fit between the simulated and observed runoff in different ways such as peak weighted RMS error, percent error peak, percent error volume, sum absolute residuals, sum squared residuals, and time-weighted error (USACE-HEC, 2006). This study used the peak weighted RMS error as the objective function.

\subsection{Comparison of the two basin models}

Numerous goodness of fit statistical criteria are proposed in the literature for evaluating hydrological modeling results. In this study the Nash-Sutcliffe index (Nash and Sutcliffe, 1970) is used as the criteria to compare the HECHMS model performance under two scenarios of basin models mentioned in section 3.1. The ASCE Watershed Management Committee (ASCE 1993) recommends the Nash-Sutcliffe index for evaluation of rainfall runoff models. Merz and Bloschl (2004) used the index in the calibration and verification of catchment model parameters. Kalin et al. (2003) used the index as a goodness-of-fit indicator for a storm event model. It is also widely used with hydrological models (Roux and Dartus, 2006; Norbiato et al., 2008; Ao et al, 2006; Moreda et al, 2006; Hogue et al, 2006). The use of the index for a wide variety of model types indicates its flexibility as a goodness-of-fit statistic. When the Nash Sutcliffe model efficiency coefficient is between 0 and 1 , the model does better than simply forecasting. The closer the Nash Sutcliffe model efficiency coefficient to one, the better the performance of the model.

Nash Sutcliffe model efficiency coefficient is defined as:

$$
E=1-\frac{\sum_{t=1}^{T}\left(Q_{0}^{t}-Q_{m}^{t}\right)^{2}}{\sum_{t=1}^{T}\left(Q_{0}^{t}-\overline{Q_{0}}\right)^{2}}
$$

Where, $Q_{0}^{t}$ is observed discharge, $Q_{m}^{t}$ is modeled discharge, and $\bar{Q}_{0}$ is average observed discharge at time $t$.

McCuen et.al (2006) indicated that the Nash Sutcliffe model efficiency coefficient is a good performance criterion indicator as long as the sample size is moderate (i.e., number of ordinates are more than 12). In this study the sample size (i.e. the number of days) was always more than twelve and the time interval was one day making it very much applicable for this study. 
Table 2 Parameters used in the two basin models shown in Figures 3 and 4

\begin{tabular}{|c|c|c|c|c|c|c|c|c|c|c|c|}
\hline \multirow{2}{*}{$\begin{array}{l}\text { Basin } \\
\text { model }\end{array}$} & \multirow[t]{2}{*}{ Subbasin } & \multicolumn{3}{|c|}{ Loss -Initial and constant } & \multicolumn{2}{|c|}{ Transform - Clarks UH } & \multicolumn{2}{|c|}{ Baseflow - Recession } & \multirow[b]{2}{*}{$\begin{array}{l}\text { Recession } \\
\text { Constant }\end{array}$} & \multirow[b]{2}{*}{$\begin{array}{l}\text { Threshold } \\
\text { type }\end{array}$} & \multirow[b]{2}{*}{$\begin{array}{l}\text { Ratio } \\
\text { to } \\
\text { peak }\end{array}$} \\
\hline & & $\begin{array}{l}\text { Initial } \\
\text { loss } \\
\mathrm{mm} \\
\end{array}$ & $\begin{array}{l}\text { Constant } \\
\text { rate } \mathrm{mm} / \mathrm{h}\end{array}$ & $\begin{array}{l}\text { Impervious } \\
\%\end{array}$ & $\begin{array}{l}\text { Time of } \\
\text { concentration } \\
\mathrm{h}\end{array}$ & $\begin{array}{l}\text { Storage } \\
\text { Cocfficient } \\
\mathrm{h}\end{array}$ & $\begin{array}{l}\text { Initial } \\
\text { type }\end{array}$ & $\begin{array}{l}\text { Initial } \\
\text { discharge } \\
\mathrm{m}^{3} / \mathrm{s} \\
\end{array}$ & & & \\
\hline \multirow{4}{*}{$\begin{array}{l}4 \\
\text { basin } \\
\text { model }\end{array}$} & Ellegawa & 1 & 0.00 & 1 & 72 & 48 & Discharge & 65.00 & 0.90 & Ratio to Peak & 0.05 \\
\hline & Horana & 2 & 0.30 & 1 & 72 & 48 & Discharge & 25.00 & 0.80 & Ratio to Peak & 0.20 \\
\hline & Sinharaja & 5 & 3.00 & 1 & 96 & 96 & Discharge & 30.00 & 0.80 & Ratio to Peak & 0.20 \\
\hline & Sri Pada & 1 & 0.20 & 2 & 24 & 48 & Discharge & 15.00 & 0.80 & Ratio to Peak & 0.40 \\
\hline \multirow{10}{*}{$\begin{array}{l}10 \\
\text { basin } \\
\text { model }\end{array}$} & Agalawaththa & 3 & 0.90 & 1 & 24 & 48 & Discharge & 10.00 & 0.60 & Ratio to Peak & 0.20 \\
\hline & Ayagama & 2 & 0.05 & 2 & 96 & 72 & Discharge & 15.00 & 1.00 & Ratio to Peak & 0.10 \\
\hline & Balangoda & 3 & 0.30 & 10 & 48 & 48 & Discharge & 14.00 & 0.80 & Ratio to Peak & 0.20 \\
\hline & Horana & 3 & 0.20 & 1 & 48 & 24 & Discharge & 4.00 & 1.00 & Ratio to Peak & 0.20 \\
\hline & Kalawana & 2 & 0.90 & 2 & 36 & 72 & Discharge & 4.00 & 0.60 & Ratio to Peak & 0.20 \\
\hline & Kuruwita & 2 & 0.05 & 1 & 24 & 24 & Discharge & 20.00 & 1.00 & Ratio to Peak & 0.10 \\
\hline & Malwala & 5 & 0.20 & 2 & 24 & 36 & Discharge & 14.00 & 0.80 & Ratio to Peak & 0.20 \\
\hline & Rakwana & 2 & 0.05 & 2 & 24 & 36 & Discharge & 12.00 & 1.00 & Ratio to Peak & 0.20 \\
\hline & Sinharaja 1 & 2 & 2.50 & 2 & 36 & 72 & Discharge & 10.00 & 0.60 & Ratio to Peak & 0.20 \\
\hline & Sinharaja 2 & 2 & 2.50 & 1 & 36 & 72 & Discharge & 10.00 & 0.60 & Ratio to Peak & 0.20 \\
\hline
\end{tabular}

Table 3 Parameters used in for channel flow (reaches) of the two basin models shown in Figures 3 and 4

\begin{tabular}{|c|c|c|c|c|c|}
\hline Basin Model & Reach & Model & Muskingum K h & Muskingum $X$ & Lag min \\
\hline \multirow[t]{2}{*}{4 basin model } & EllagawaToPutupaula & Muskingum & 12 & 0.4 & \\
\hline & RatnapuraToEllagawa & Muskingum & 48 & 0.5 & \\
\hline \multirow[t]{6}{*}{10 basin model } & MReach3 & Muskingum & 36 & 0.1 & \\
\hline & MReach4 & Muskingum & 24 & 0.1 & \\
\hline & MReach5 & Muskingum & 12 & 0.1 & \\
\hline & MReach2 & Lag & & & 720 \\
\hline & MsReach1 & Lag & & & 2160 \\
\hline & MsReach2 & Lag & & & 720 \\
\hline
\end{tabular}




\section{Analysis and Results}

\subsection{Calibration and Verification}

Four selected storm events are used forcalibration and verification of both basin models. For the calibration and optimization of parameter values the rainfall event occurred in November 1992 (Table No.1) was used while the other three events were used for verification. Subsequently, for a comparison, calibration of the models was carried out based on the rainfall event occurred in May 1993 and the resulting models were verified using the other three rainfall events given in Table 1.

The parameters of the models were first assumed with the knowledge of the Kalu-Ganga River

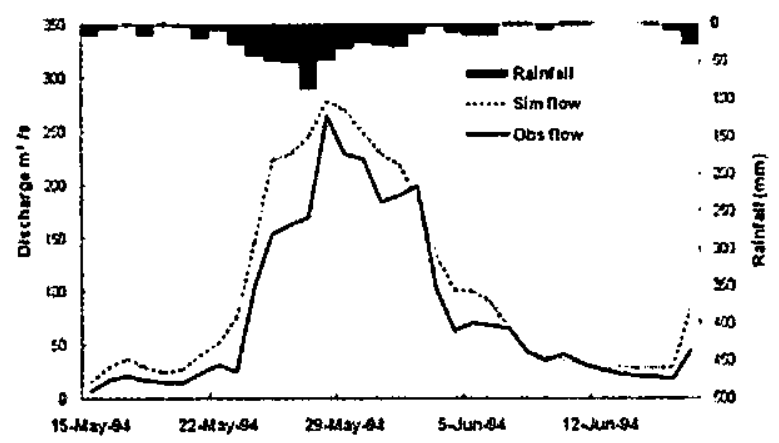

Figure 5a. Rainfall runoff at Ratnapura for May 1994 rainfall event for 4 basin model

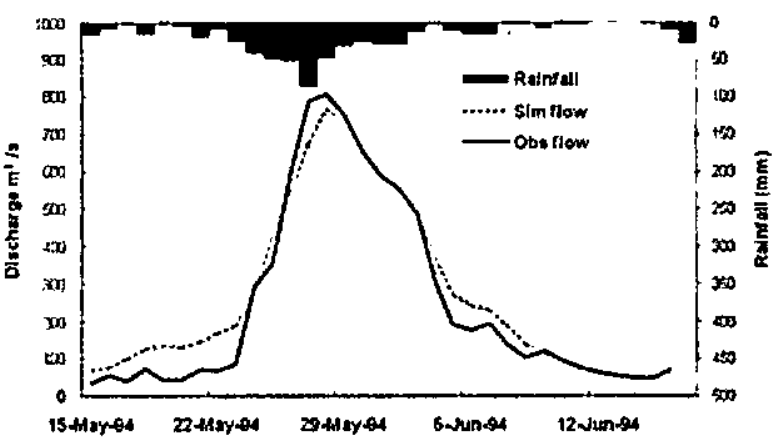

Figure 5b. Rainfall runoff at Ellagawa for May 1994 rainfall event for 4 basin model

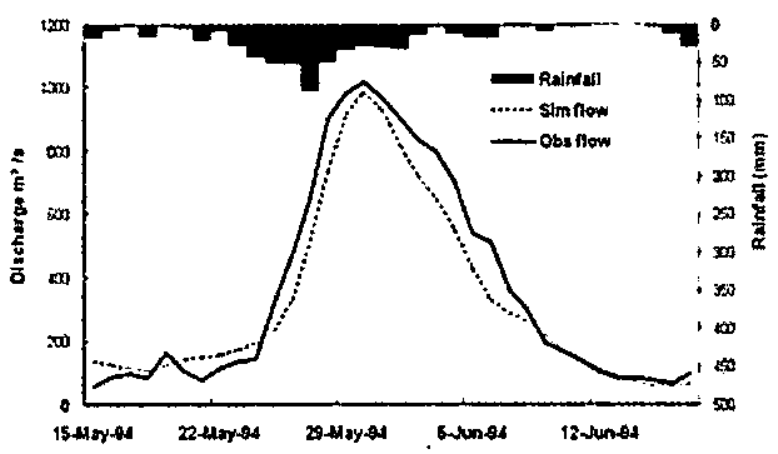

Figure 5c. Rainfall runoff at Putupaula for May 1994 rainfall event for 4 basin model basin. Then these parameters were optimized using the calibration process in the HEC-HMS model. Optimization of parameters of the sub basins above the Ratnapura gauging station were conducted first using the discharge data of the Ratnapura gauging station. Next optimization of the parameters of the sub basins and reaches above Ellagawa and below Ratnapura gauging stations were conducted. Finally, the parameters of the sub basins and reaches above the last gauging station at Putupaula and below Ellagawa gauging station were performed. Tables 2 and 3 present the parameters resulted for sub basins and reaches for 4 basin model and 10 basin model after optimization respectively.

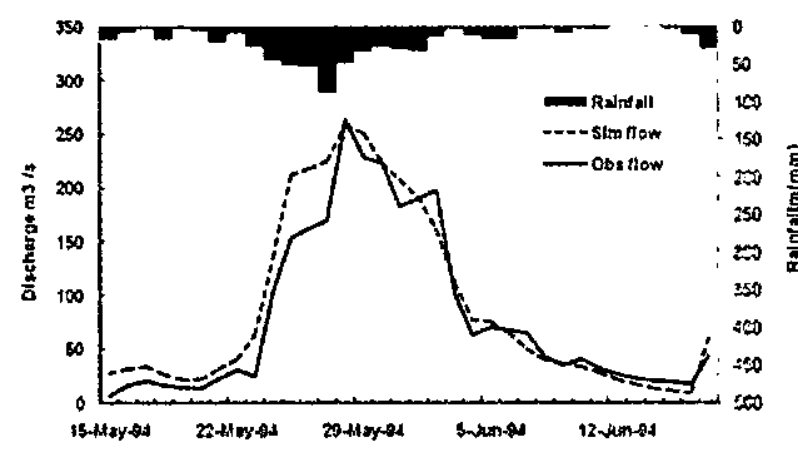

Figure 6a. Rainfall runoff at Ralmapura for May 1994 rainfall event for 10 basin model

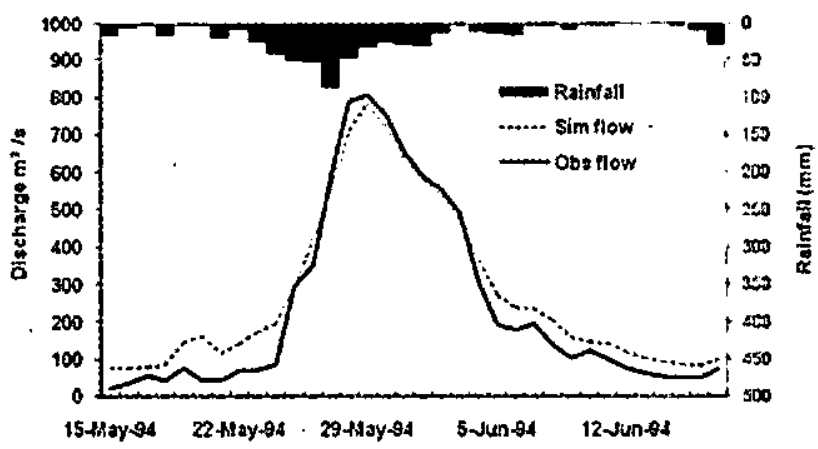

Figure 6b. Rainfall runoff at Ellagawa for May 1994 rainfall event for 10 basin model

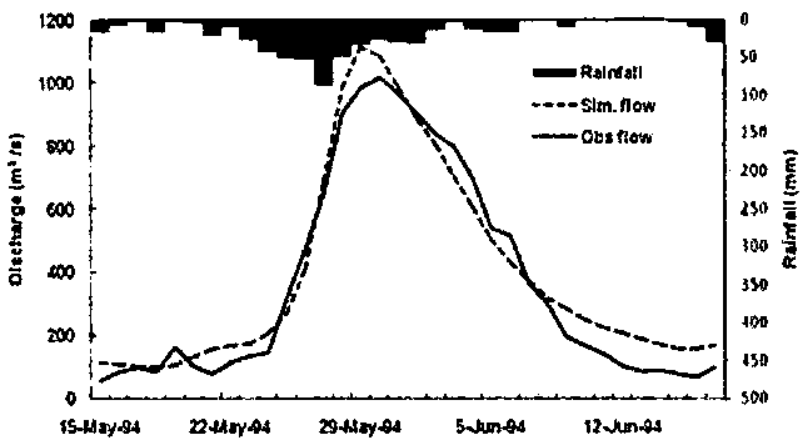

Figure 6c. Rainfall runoff at Putupaulaa for May 1994 rainfall event for 10 basin model 


\subsection{Comparison of the two basin models}

Hydrographs for the three gauging stations, Ratnapura, Ellagawa and Putupaula (Figure 1) for 1994 May rainfall event for the two sub basin models are given in Figures $5 \mathrm{a}$ to 5 c for 4 basin model and $6 a$ to $6 c$ for 10 basin model for graphical evaluation of the model performance for both scenarios of sub basin level.

From thegraphsitisevidentthatthepeakdischarge agrees with observed value. The time to peak also agrees well with the observed value in both basin models and for all the three gauging stations.

Table 4 Nash Sutcliffe model efficiency coefficient for observed gauging points for the 4 basin model

\begin{tabular}{lccl}
\hline Event & -Ratnapura & Ellagawa & Putupaula \\
\hline 1993 May & 0.900334 & 0.949387 & 0.858501 \\
\hline 1993 Oct & 0.887190 & 0.961047 & 0.771844 \\
\hline 1994 May & 0.835777 & 0.964079 & 0.940262 \\
\hline & 0.836231 & 0.896588 & 0.934740 \\
\hline
\end{tabular}

Table 5 Nash Sutcliffe model efficiency coefficient for observed gauging points for the 10 basin model

\begin{tabular}{llll}
\hline Event & Ratnapura & Ellagawa & Putupaula \\
\hline 1993 May & 0.920920 & 0.942308 & 0.700043 \\
\hline 1993 Oct & 0.932305 & 0.942336 & 0.803982 \\
\hline 1994 May & 0.912886 & 0.959965 & 0.957709 \\
\hline & 0.924131 & 0.922629 & 0.860085 \\
\hline
\end{tabular}

The two basin models were compared using Nash Sutcliffe model efficiency coefficient calculated for computed discharge and the observed discharge at the three gauging stations, Ratnapura, Ellagawa and Putupaula. Table 4 shows the Nash Sutcliffe model efficiency coefficient yielded for basin model with 4 sub basins while Table 5 presents them for the basin model with 10 sub basins for the three rainfall events considered. Last rows in both tables represent the average value for all three rainfall events.

Table 6 and Table 7 give the Nash Sutcliffe model efficiency coefficient for observed gauging points for the 4 basin model and 10 basin model with parameters optimized using 1993 May rainfall event.

\section{Discussion and Conclusions}

\subsection{Discussion}

Figures $5 \mathrm{a}$ to $5 \mathrm{c}$ for the 4 basin model and Figures $6 \mathrm{a}$ to $6 \mathrm{c}$ for the 10 basin model indicate that the overall performance of these models as very satisfactory since the model resulted peak runoffs coincide with the observed peak runoffs for all three gauging stations. There were no much differences between the two scenarios of the basin models used at three gauging stations.

The model performance for both the 4 basin model and the 10 basin model can be accepted well as observed in Tables 4 and 5. In the 4 basin model the model performance was very good at Putupaula and the 10 basin model performed well at Ratnapura and Ellagawa since Nash Sutcliffe coefficient is close to one in these cases.

Table 6 Nash Sutcliffe model efficiency coefficient for observed gauging points for the 4 basin model with parameters optimized using 1993 May rainfall event

\begin{tabular}{llll}
\hline Event & Ratnapura & Ellagawa & Putupaula \\
\hline 1992 Nov & 0.880166 & 0.732225 & 0.845788 \\
\hline 1993 Oct & 0.916842 & 0.865624 & 0.816133 \\
\hline 1994 May & 0.930893 & 0.907112 & 0.933217 \\
\hline & 0.9093 & 0.834987 & 0.865046 \\
\hline
\end{tabular}

Table 7 Nash Sutcliffe model efficiency coefficient for observed gauging points for the 10 basin model with parameters optimized using 1993 May rainfall event

\begin{tabular}{llll}
\hline Event & Ratnapura & Ellagawa & Putupaula \\
\hline 1992 Nov & 0.915299 & 0.773556 & 0.888731 \\
\hline 1993 Oct & 0.933920 & 0.894022 & 0.813787 \\
\hline 1994 May & 0.894805 & 0.905383 & 0.945018 \\
\hline & 0.914674 & 0.857654 & 0.882512 \\
\hline
\end{tabular}

The Nash Sutcliffe model efficiency coefficient values yielded for the two models with the parameters optimized using 1993 May rainfall event show that there is no much difference between the outputs obtained from the two calibrations.

With respect to runoff simulation at Putupaula gauging station the 4 basin model performs better than the other as indicated by the Nash Sutcliffe model efficiency coefficient of 0.934740 . However, when the other two gauging stations 
are considered the 10 basin model performs a little better. Though in general rainfall representation and the other sub basin scale parameters should improve when the model has more sub basins, it does not happen in case of the Putupaula gauging station. This may be due to the different spatial distribution of rainfall in the Sinharaja watershed which is very large. If the gauging station was situated before Sinharaja runoff enters the Kalu-Ganga River a better rainfall runoff simulation would have resulted at Putupaula gauging station.

\section{Conclusions}

The results based on the Nash Sutcliffe model efficiency coefficient and the graphical evaluation show that the HEC-HMS model is well suited for the simulation of rainfall runoff of the KaluGanga River basin, regardless of the sub-basin's scale. Clark unit hydrograph method available in HEC-HMS model to transform rainfall into runoff is suitable to model the Kalu-Ganga River basin. However, for channel routing both lag time and Muskingum channel flow routing methods have to be used depending on the characteristics of the channel. Birkhead and James (2002) mentioned that Muskingum procedures account explicitly for channel storage only, and not total storage along a river reach which may include lateral inflows (tributary or diffuse inputs) or outflows, losses (recharge of groundwater aquifers or evapotranspiration), and temporal changes in bank storage. Therefore, the model sometimes generates unrealistic values for Muskingum parameter during the calibration. However, though the lower reaches of the Kalu-Ganga River bear such characteristics the Muskingum method was able to successfully model the lower reaches of the Kalu-Ganga River. The Lag time channel flow routing method which is suitable to steeper channel lengths was found to be applicable for the upper reaches of the river.

Since the difference between the results obtained from the 4 basin model and the 10 basin model is negligible it can be concluded that there is no scale effect (that is the number of sub basins) in modeling the Kalu-Ganga River basin using HEC-HMS for flood prediction. The model parameters resulted from the calibrations carried out using two rainfall events were observed to be very similar.

\section{Acknowledgements}

Authors would like to acknowledge the University Grant Commission for providing necessary funds for carrying out this research.

\section{Reference}

1. Al-Sabhan, W., Mulligan, M., Blackburn, G.A., (2003). A real-time hydrological model for flood prediction using GIS and the WWW, Computers, Environment and Urban Systems, 27 (2003) 9-32.

2. Ao, T., Ishidaira, H., Takeuchi, K., Kiem, A.S., Yoshitari, J., Fukami, K., Magome, J. (2006). "Relating BTOPMC model parameters to physical features of MOPEX basins", Journal of Hydrology, 320, 84-102.

3. ASCE Task Committee on Definition of Criteria for Evaluation of Watershed

4. Models of the Watershed Management, Irrigation, and Drainage Division (ASCE). (1993). "Criteria for evaluation of watershed models." Journal of Irrigation and Drainage Engineering, 119(3), 429-442.

5. Bakir, M., Xingnan, Z., (2008) “ GIS-Based Hydrological Modeling: A Comparative Study of HEC-HMS and The XINANJIANG Model", Proceedings of Twelfth International Water Technology Conference, IWTC12 2008 Alexandria, Egypt, 855-865.

6. Birkhead, A.L., and James C.S., (2002) Muskingum river routing with dynamic bank storage, Journal of Hydrologic Engineering, 264, 113-132.

7. Chu, X., and Steinman, A. (2009). "Event and Continuous Modeling with HEC_HMS." Journal of Irrigation and Drainage Engineering, 135(1), 119-124.

8. Clark, C.O. (1945). "Storage and the unit hydrograph." Transactions, ASCE, 110, 14191446.

9. Dooge, J.C.I., Strupczewski, W.B., Napiorkowski, J.J., 1982. Hydrodynamic derivation of storage parameters of the Muskingum model. Journal of Hydrology 54, 371- 387 . 
10. Jarvis A., Reuter, H.I., Nelson, A. and E. Guevara (2008) Hole-filled seamless SRTM data V4, International Centre for Tropical Agriculture (CIAT), available at http://srtm. csi.cgiar.org.

11. Horgue, T.S., Gupta, H., Sorooshian, S. (2006). "A 'User-Friendly' approach to parameter estimation in hydrologic models" Journal of Hydrology, 320, 202-217.

12. Kalin, L., Govindaraju, R. S., and Hantush, M. M., (2003) "Effect of geomorphological resolution on modeling of runoff hydrograph and sedimentograph over small watersheds." Journal of Hydrology, 276, 89-111.

13. Khakbaz, B., Imam, B., Hsu, K,, Sorooshian, S., (2009). From lumped to distributed via semidistributed: Calibration strategies for semidistributed hydrologic models, Journal of Hydrology, doi:10.1016/j.jhydrol.2009.02.021.

14. Knebla, M.R., Yanga, Z.L., Hutchisonb, K., Maidment D.R., (2005), Regional scale flood modeling using NEXRAD rainfall, GIS, and HEC-HMS/RAS: a case study for the San Antonio River Basin Summer 2002 storm event, Journal of Environmental Management, 75 (2005) 325-336.

15. McCuen, R.H., Knight, Z., Cutter, A.G. (2006). "Evaluation of the Nash-Sutcliffe Efficiency Index", Journal of Hydrologic Engineering, $11(6), 597-602$.

16. Merz, R., and Bloschl,G.,(2004) "Regionalization of catchment model parameters." Journal of Hydrology, 287, 95-123.

17. Moreda, F., Koren, V., Reed, S., Smith, M. (2006) "Parameterization of distributed hydrological models: learning from the experience of lumped modeling" Journal of Hydrology, 320, 218-237.

18. Nandalal, H.K. and Ratnayake, U.R. (2008), "Comparison of a river network delineated from different digital elevation models available in public domain", Proceedings, 29th Asian Conference on Remote Sensing, CD_ ROM1, Colombo, Sri Lanka.

19. Nash, J.E., and Sutcliffe, J.V. (1970) River flow forecasting through conceptual models, part-1- A discussion of principles. Journal of Hydrology, 10(3), 282-290.
20. Penman, H.L. (1961). "Weather, plant and soil factors in hydrology" Weather, 16, 207-219.

21. Neary, V. S., Habib, E., Flening, M., (2004), Hydrologic Modeling with NEXRAD Precipitation in Middle Tennessee, Journal of Hydrologic Engineering, 9(5), 339-349.

22. Norbiato D., Borga, M., Esposti, S. D., Gaume, E., Anquetin, S., (2008). "Flash flood warning based on rainfall threshoids and soil moisture conditions: an assessment for gauged and ungauged basins", Journal of Hydrology, 362, 274-290.

23. Pingel, N.P.E., Jones, C., Ford, D., (2005), Estimating Forecast Lead Time, Natural Hazards Review, 6(2), 60-66.

24. Refsgaard,J.C., (1996) Terminology, Modelling, Protocol and Clasification of Hydrological Model Codes, in Abbott, M.B. and Refsgaard, J.C. (eds.) Distributed hydrological Modelling (Kluwer Academic Publishers), The Netherlands, 17-39.

25. Roux, R., and Dartus, D (2006). "Use of parameter optimization to estimate a flood wave: Potential application to remote sensing of rivers" Journal of Hydrology, 328, 258-266.

26. Singh VP, Woolhiser AD. (2002). Mathematical modeling of watershed hydrology. Journal of Hydrologic Engineering 7(4): 270-292.

27. Tung, Y.K., 1985. River flood routing by nonlinear Muskingum method. J. Hydraul. Engng. 111 (12), 1447-1460.

28. United States Army Corps of Engineers, Hydrologic Engineering Center (USACE. HEC). (2006). Hydrologic modeling system HEC-HMS technical user's manual, Davis, California.

29. United States Army Corps of Engineers, Hydrologic Engineering Center (USACE. HEC-GeoHMS). (2006). Geospatial Hydrologic Modeling Extension, User's Manual, Davis, California.

30. Yoon, J., Padmanabhan, G., 1993. Parameter estimation of linear and nonlinear Muskingum models. J. Water Resour. Planning Mgmt $119(5), 600-610$. 